\title{
Metastatic Biphasic Primitive Tumor in the Mandible of a Child
}

\author{
Tiago Novaes Pinheiro ${ }^{1}$ Milena Gomes Melo Leite ${ }^{2}$ Fábio Arruda Bindá ${ }^{3}$ \\ André Luiz Tannus Dutra ${ }^{4}$ Naelka Sarmento ${ }^{4} \quad$ Lioney Nobre Cabral ${ }^{5} \quad$ Alberto Consolaro $^{6}$ \\ Carlos Eduardo Bacchi
}

${ }^{1}$ Department of Oral Pathology and Oral Medicine, Surgical Pathology and Oral and Maxillofacial Pathology Service,

Amazonas State University, Cachoeirinha, Manaus-AM, Brazil

2Department of Oral Pathology and Oral Medicine,

Surgical Pathology and Oral and Maxillofacial Pathology Service,

Amazonas State University, Cachoeirinha, Manaus-AM, Brazil

${ }^{3}$ Department of Head and Neck Oncology, Fundação Centro de

Controle de Oncologia do Estado do Amazonas, Planalto,

Manaus-AM, Brazil

${ }^{4}$ Department of Pediatric Dentistry, Amazonas State University,

Cachoeirinha, Manaus-AM, Brazil

${ }^{5}$ Department of Oral Pathology and Oral Medicine, Amazonas State

University, Cachoeirinha, Manaus-AM, Brazil

${ }^{6}$ Department of Oral Pathology, Bauru School of Dentistry,

University of São Paulo, Bauru-SP, Brazil

${ }^{7}$ Department of Pathology, Laboratório Bacchi Ltd., LB,

Botucatu-SP, Brazil

\author{
Address for correspondence Milena Gomes Melo Leite, \\ Undergraduate Dentistry Student, Superior School of Health Science, \\ Amazonas State University, Avenue Carvalho Leal, 1777, \\ Cachoeirinha, 69065-001, Manaus-AM, Brazil \\ (e-mail: milena.gomesmelo97@gmail.com).
}

\begin{abstract}
Keywords

- PNET

- mucoepidermoid carcinoma

- carcinosarcoma

- Ewing's sarcoma

- odontogenic tumors

- metastasis

Pediatric mandibular tumors present an aggressive biological behavior and difficult diagnosis. A wide range of odontogenic and nonodontogenic tumors comprise the spectrum of these lesions. We report a case of a 1-year-old male child patient showing facial asymmetry symptomatic of an expansive lesion extending throughout the body and ramus of the left hemimandible with a diameter of $8 \mathrm{~cm}$. The histopathological report suggested a high-grade mucoepidermoid carcinoma (MEC), recommending further immunohistochemical investigation of the ectomesenchymal or neuroectodermal origin of the tumor cells. The patient evolved with extensive bilateral pleural effusion followed by metastasis in the middle third of the right humerus, and died 2 months after the first biopsy procedure by acute renal failure with tubular necrosis, before a final inconclusive immunohistochemical report was reached. The lack of resources for less-favored regions of Brazil impairs rapid biomolecular examinations such as immunohistochemical resulting in delay of appropriate therapeutic procedures.
\end{abstract}

\section{Introduction}

Aggressive tumors are defined by their clinical and radiographic features. Criteria include clinically displaying an expansive accelerated process greater than $5 \mathrm{~cm}$ with frequent recurrence. Imaging characteristics include thinning of the cortical bone, tooth displacement, and root resorption. ${ }^{1}$
Difficulties in diagnosis of these lesions arise from identical or unclear clinical and radiographic features for a broad range of lesions. ${ }^{2}$

Maxillofacial tumors are classified as odontogenic or nonodontogenic, as well as malignant or benign. ${ }^{3}$ Odontogenic tumors originate from epithelial, ectomesenchymal, and/ or mesenchymal tooth-forming tissues., ${ }^{3,4}$ Nonodontogenic 
tumors may be derived from mesenchymal tissue or from osseous tissue and express locally aggressive destruction or malignancy. ${ }^{3}$

The most prevalent malignant tumors affecting the pediatric population are rhabdomyosarcomas and nonrhabdomyomatous sarcomas. ${ }^{5}$ The latter include the Ewing family of tumors, osteosarcoma, synovial sarcoma, malignant fibrous histiocytoma, malignant peripheral nerve sheath tumors, and fibrosarcoma. ${ }^{5,6}$

We present a case of a 1-year-old child who demised with a rare disease: an aggressive primitive tumor with fulminant progression, and histopathological profile, with a lethal resolution after 2 months from the first clinical examination. The importance of rapid diagnosis and clinical actions to prevent such unfavorable outcomes is discussed.

\section{Case Report}

A 1-year-old male child patient of mixed ethnicity, was referred to the oral medicine service of the author's institution, showing facial asymmetry symptomatic of an expansive lesion extending throughout the body and ramus of the left hemimandible with a diameter of $8 \mathrm{~cm}$. Clinically, the tumor exhibited superficial telangiectasia, crackling consistency at palpation, and similarity to adjacent mucosa ( $\mathbf{- F i g . ~ 1 ) . ~}$ Radiographic findings revealed an irregular lytic radiolucency involving a deciduous tooth and a thinning line of cortical bone ( - Fig. 2). The first incisional biopsy procedure was

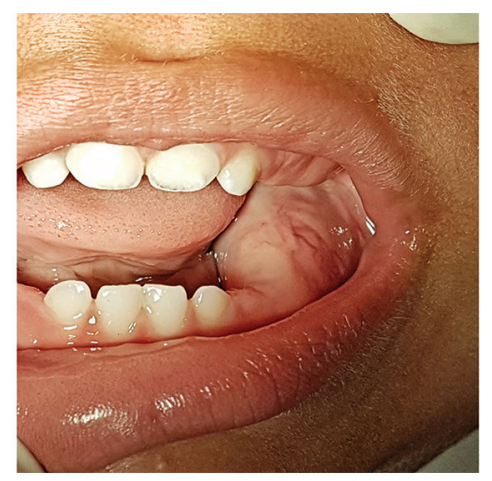

Fig. 1 Expansive lesion extending into body and ramus in left hemimandible with superficial telangiectasia, similar to adjacent mucosa.

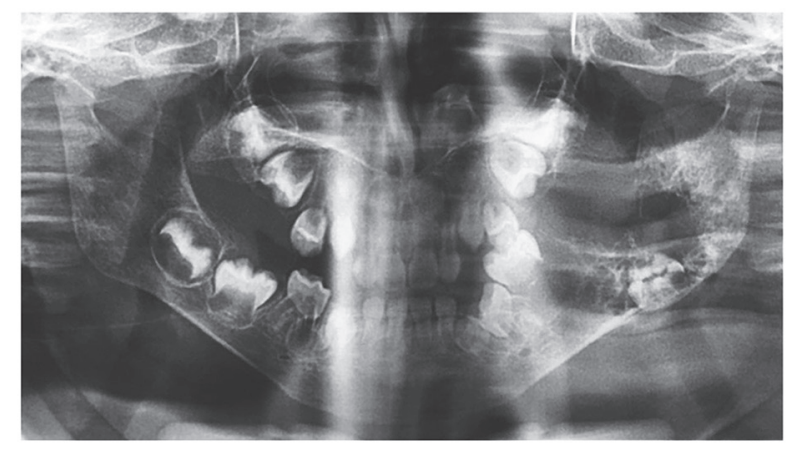

Fig. 2 Irregular lytic radiolucency involving primary mandibular left first molar (tooth \#74) and cortical bone destruction. performed under general anesthesia, with a clinical hypothesis of Ewing's sarcoma, osteosarcoma, or odontogenic myxoma. Unfortunately, the extracted specimen was considered insufficient for histopathological diagnosis. A second incisional biopsy was taken 2 weeks after the first attempt. At this point, the lesion had doubled its size clinically. During the surgical procedure, it was noted that the evolvement of the alveolar bone in the cervical region of the primary mandibular left first molar (tooth \#74) had extended.

The second histopathological evaluation found chondroid tissue infiltrated by spindled myoepithelial cells with areas of canalicular formation, spindle cells with pleomorphism cells and nuclei, hyperchromatism, and figures of mitosis, some atypical ( - Fig. 3). Hyperchromatic stratified epithelial cords and islets were observed. A positive reaction to periodic acidSchiff staining (PAS) with central clear cells of pleomorphic nuclei was also detected ( - Fig. 4). The histopathological report suggested a high-grade mucoepidermoid carcinoma (MEC), recommending further immunohistochemical investigation of the ectomesenchymal or neuroectodermal origin of the tumor cells.

The blocs were referred to a private histopathologic consulting service for immunohistochemical panel analysis. The immunohistochemical result is shown in -Table 1 and - Fig. 5. The epithelial component exhibited primitive morphological appearance, perineural noninfiltration, and absence of necroses areas. The conjunct findings discarded MEC and favored a diagnosis of biphasic neoplasia of primitive nature with spindled cell component.

The patient was referred to the referenced cancer center for treatment. The medications used during his hospitalization period are listed in - Table $\mathbf{2}$. Complementary diagnostic exams following key diagnostic findings are listed in -Table 3 and - Fig. 6. He was referred to chemotherapy treatment; however, he evolved with anasarca, mixed acidbase disorders, hydroelectrolyte imbalance, and due to his respiratory deterioration, he was submitted to tracheotomy, and could not start the treatment cycle.

The patient died 2 months after the first biopsy procedure by acute renal failure with tubular necrosis, before a final immunohistochemical report was reached. This final report was still inconclusive and suggested a possible differential diagnosis of a malignant odontogenic tumor.

\section{Discussion}

The histopathological profile revealed some microscopic features suggestive of a high-grade MEC, such as PAS positivity with central clear cells of nuclear pleomorphism, mitotic activity, and hyperchromatic basal cell cords and islets. Also, the spindled myoepithelial cells resembled the histopathology of pleomorphic adenoma, increasing the possibility of a salivary tumor with bone invasion. ${ }^{7.8}$

The ectomesenchymal origin of the tumor does not exclude possible differential diagnoses including odontogenic tumors, and the neuroectodermal origin related it to primitive tumors. The ectomesenchyma and/or mesenchyma is derived from embryonic connective tissue differentiated 


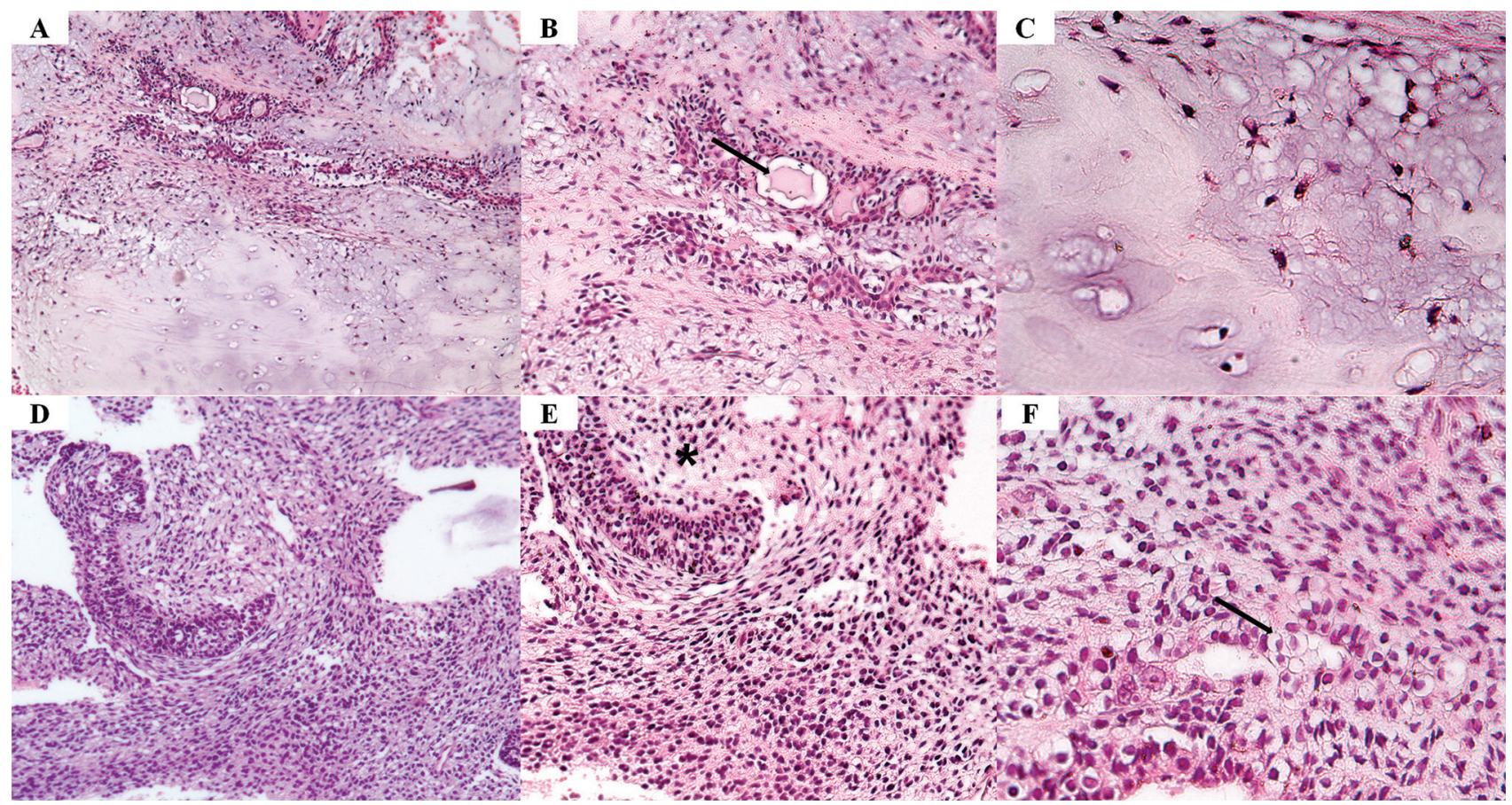

Fig. 3 (A) Magnification 100x, hematoxylin and eosin (HE) stain revealing chondromyxoid stroma infiltrated by spindled myoepithelial cells with areas of epithelial cells arranged in tubules. (B) Magnification 200x, HE stain exhibiting nests of stratified epithelium in ductiform structure surrounding amorphous eosinophilic material (arrow). (C) Magnification 400x, HE stain evidencing chondromyxoid stroma. (D) Magnification 100x, HE stain, hypercellularized biphasic neoplastic pattern of the lesion. (E) Magnification 200x, HE stain revealing pleomorphic fusiform cells stroma with islands and nests of stratified epithelium featuring hyperchromatic nuclei with eventual atypical mitotic figures, mesenchyme tissue (asterisk). (F) Magnification 400x, HE stain, clear cell (arrow).

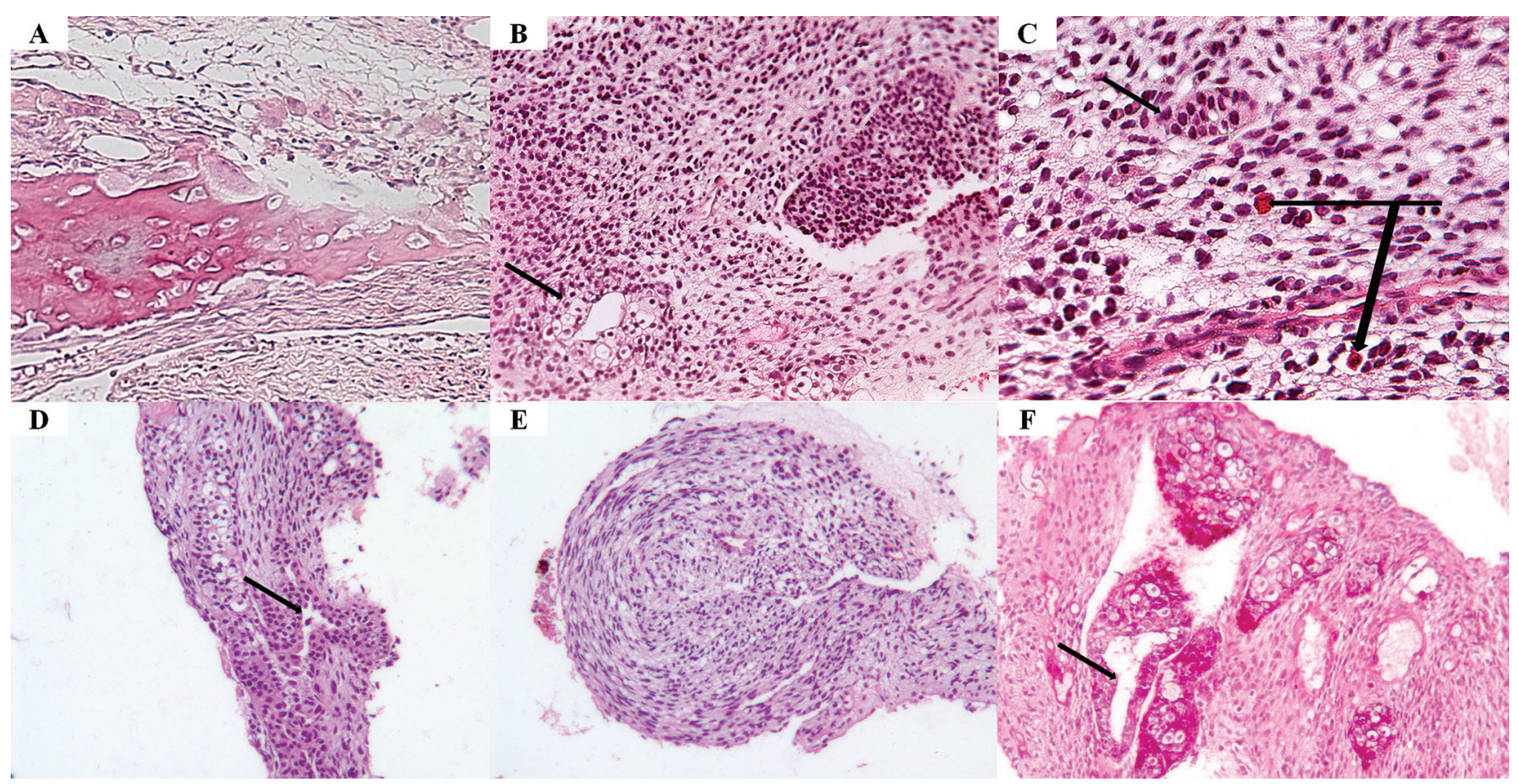

Fig. 4 (A) Magnification 200x, hematoxylin and eosin (HE) stain, myxoid tissue, bone reabsorption. (B) Magnification 200x, HE stain, pleomorphic fusiform cells stroma with islands of stratified epithelium featuring hyperchromatic nuclei and clear cells in a ductiform formation (arrow). (C) Magnification 400x, HE stain, islet of epithelium (left arrow), and two eosinophils cells (right arrow). (D) Magnification 100x, HE stain, epithelium with clear cells and ductiform structure (arrow). (E) Magnification 100x, HE stain, stroma with fusiform hyperchromatic fibroblasts in storiform pattern. (F) Magnification 100x, periodic acid-Schiff positive epithelium with central clear cells of pleomorphic nuclei in a tubular formation (arrow). 
Table 1 Immunohistochemical results in the present case

\begin{tabular}{|l|l|}
\hline Marker & Positivity \\
\hline DAK-p63 & + \\
\hline AE1/AE3 & + \\
\hline S-100 polyclonal & + \\
\hline Calp & Focally + \\
\hline CD99 & Focally + \\
\hline CDK4 & - \\
\hline MDM2 & - \\
\hline
\end{tabular}

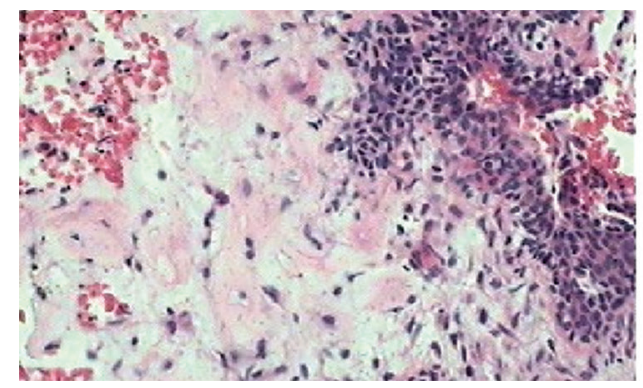

Fig. 5 Magnification 200x, immunohistochemical marker AE1/AE3 positive.

from neural crest cells (NCCs) sourced from neuroectodermal tissue. NCCs have a potential role in the development of the face and teeth. ${ }^{9}$

The neuroectodermal origin of primitive tumors is related to the embryologic aspect of NCCs, whereas the cells of Ewing's sarcoma/primitive neuroectodermal tumor (PNET) originate from the primitive neural crest. ${ }^{10}$ Another important outcome sustaining Ewing's sarcoma/PNET is the PAS positivity marked in histopathological and S-100 stains in the immunohistochemical panel (-Table 1). ${ }^{7}$ The positive reaction to PAS appears in several head and neck tumor types, such as granular cell tumor, MEC, clear cell carcinoma, clear cell odontogenic carcinoma, secretory carcinoma, Ewing's sarcoma/PNET, and others. ${ }^{7}$ The S-100 protein was previously believed to be of neural crest origin, but it manifested in vastly different cells. Its marking is related to cancer and associated with oral diseases such as oral mucosal melanomas. Gland tumors, including undifferentiated carcinoma and others, are also expressed by this protein. Also, tumors such as Ewing's sarcoma/ PNET exhibit S-100 positive immunoreaction.

Studies revealed S-100 marking in epithelial and ectomesenchymal structures in some odontogenic tumors, linked to NCCs. ${ }^{11}$ Molecularly, the p63 gene is primordial for noble structure formation during limb and epidermal morphogenesis, harboring adnexa organs such as teeth, glands, and hair. In oral mucosa, basal layers manifest the p63 pattern. ${ }^{12,13}$ Immunoreactivity to molecular weight cytokeratins reflects tumor cell activity, as these markers are positive in epithelial

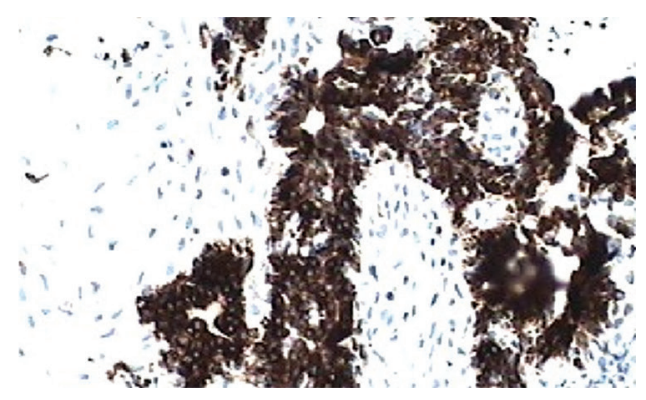

Table 2 List of medications uptake during the hospitalized period

\begin{tabular}{|l|l|}
\hline Medication & Dosage \\
\hline Calcium gluconate & $100 \mathrm{mg} / \mathrm{mL}(10 \%)$ IV \\
\hline Ranitidine & $50 \mathrm{mg} / 2 \mathrm{~mL}$ IV \\
\hline Dipyrone & $1 \mathrm{~g} \mathrm{IV}$ \\
\hline Tramadol & $50 \mathrm{mg} / \mathrm{mL}$ IV \\
\hline Ondansetron hydrochloride & $4 \mathrm{mg} / 2 \mathrm{~mL}$ IV \\
\hline Dimethicone & $75 \mathrm{mg} / \mathrm{mL}$ oral \\
\hline
\end{tabular}

Abbreviation: IV, intravenous.

cell carcinomas. ${ }^{14}$ Pancytokeratins (AE1/AE3), in normal myoepithelial cells, are negative, but their stain expresses the proliferative component of myoepithelial cells. ${ }^{15}$ Finally, calponin is a specific protein of smooth muscle, present in myofibroblast and myoepithelial cells. ${ }^{16}$

Immunostaining did not indicate MEC; however, it evidenced primitive aspect. It is important to note, though, that there are no specific markers for MECs. On the other hand, p63 stains the epidermoid structure and is an effective marker to differentiate MEC from acinic cell carcinoma and distinguish low-grade MEC from mucous retention cysts and papillary cystadenoma of the salivary glands. ${ }^{16,17}$ Yet, expression of protein p63 only in basal cells indicates normal oral epithelium, discarding a malignant nature. ${ }^{12}$

The perineural noninfiltration and absence of necrosis observed in the case did not support the malignant tumor idea. Meanwhile, the oral and maxillofacial region is a common site of benign but aggressive lesions. ${ }^{6}$

The immunohistochemical panel did not complete a diagnosis for this case and discard the MEC possibility. However, it pointed to a biphasic neoplasia and primitive epithelium, which could mean a grand range of tumors.

To fulfill the final diagnosis, additional markers could bring more important information. Soft tissue sarcomas are a diversified group comprising different histologic origins and common histopathologic features. Vimentin, a nonspecific marker, seems to react with all soft tissue tumors and is considered as a control marker preserved in the tissue. ${ }^{18}$ It is positive in most sarcomas, melanoma, some carcinomas 
Table 3 Investigative exams of the patient symptoms

\begin{tabular}{|l|l|}
\hline Medical exam & Results \\
\hline scintigraphy & $\begin{array}{l}\text { Areas of increased bone remodeling in the } \\
\text { mandible, and left and middle third of right } \\
\text { humerus }\end{array}$ \\
\hline Thorax ultrasound & Extensive bilateral pleural effusion \\
\hline Thorax CT & $\begin{array}{l}\text { Diffuse thickening of interlobular septa } \\
\text { Extensive bilateral pleural effusion } \\
\text { Mediastinal and hilar vessels without } \\
\text { changes } \\
\text { Preserved cardiac area } \\
\text { Absence of mediastinal lymph node } \\
\text { enlargement }\end{array}$ \\
\hline Head and neck CT & $\begin{array}{l}\text { Heterogeneous hypodense soft tissue } \\
\text { mass with areas of permeation necrosis, } \\
\text { and partially erodes left mandibular ramus, } \\
\text { medially displaces tongue to the right } \\
\text { In the posterior region, it occupies } \\
\text { parapharyngeal carotid space ipsilateral, } \\
\text { in close contact with the oropharyngeal } \\
\text { medial wall }\end{array}$ \\
\hline Abdomen CT & $\begin{array}{l}\text { Severe ascites, centralized bowel loops } \\
\text { Liver of normal shape, volume, and homo- } \\
\text { geneous density } \\
\text { Gallbladder of anatomical aspect } \\
\text { Spleen of normal volume, and homogene- } \\
\text { ous density } \\
\text { Anatomical pancreas } \\
\text { Kidneys of shape, topography, and normal } \\
\text { dimensions } \\
\text { Adrenal glands without changes } \\
\text { There is no evidence of retroperitoneal } \\
\text { lymph node enlargement } \\
\text { Intact bone structure } \\
\text { Normal bladder } \\
\text { Lymphedema of the lower abdominal/pel- } \\
\text { vic subcutaneous cell tissue and proximal } \\
\text { thighs }\end{array}$ \\
\hline $\begin{array}{l}\text { Muscle plan without changes } \\
\text { Absence of mass or collection } \\
\text { Intact bone structure }\end{array}$ \\
Negative \\
\hline Abrevating
\end{tabular}

Abbreviation: $\mathrm{CT}$, computed tomography.

and lymphomas, but negative in alveolar soft part sarcoma and perivascular epithelioid cell neoplasms. ${ }^{19}$ Keratin and epithelial membrane antigen are expressed unusually in some soft tissue tumors including synovial sarcoma, epithelioid sarcoma, chordoma, and myoepithelioma/myoepithelial carcinoma. ${ }^{18} \mathrm{~K}_{\mathrm{i}}-67$ (MIB1) is a nuclear proliferation marker correlated with mitotic count, cellularity, and histological grade, ${ }^{19}$ expressed at all phases of the cell cycle except the resting G0 stage. ${ }^{18}$ It allows to attain the frequency of proliferating cells. CDK4, a protein implicated in cell cycle progression, and MDM2, inhibitor of p53 transcriptional activation, are differential markers to distinguish liposarcomas from other differentiated sarcomas. ${ }^{20}$ Both are usually negative for lipoma, pleomorphic liposarcoma, and myxoid liposarcoma. ${ }^{19}$
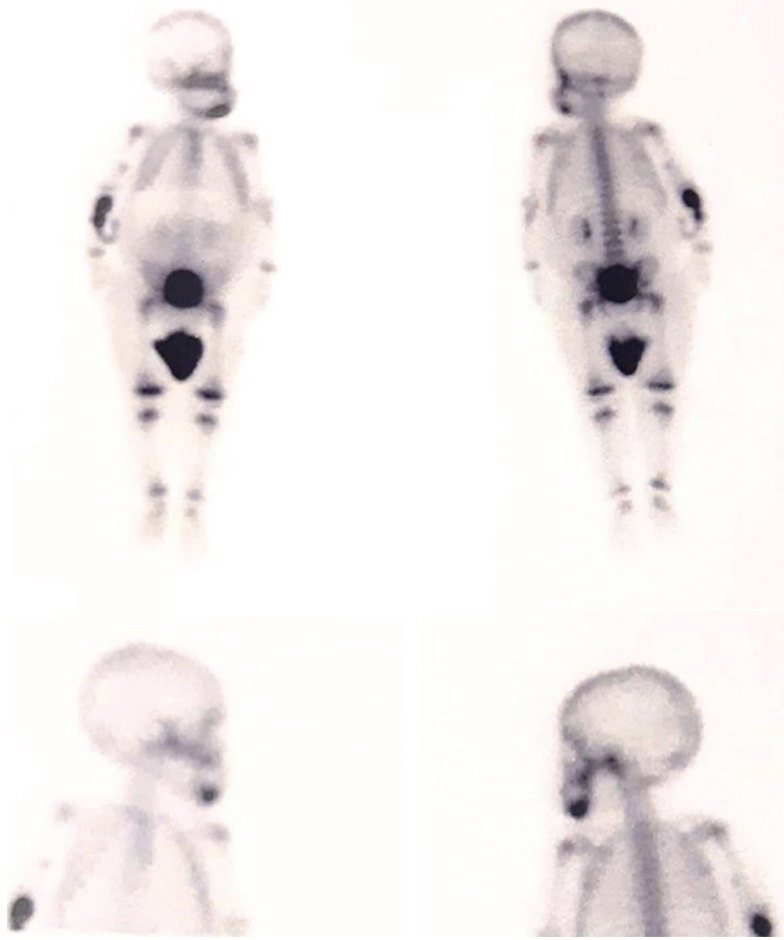

Fig. 6 Skeletal scintigraphy, using radiotracer Technetium Tc-99m with methylene diphosphonate, and dose 30 millicuries showed areas of increased bone remodeling in the mandible, and left and middle third of right humerus.

SOX9 is a sensitive marker for cartilaginous differentiation, and is useful to characterize mesenchymal chondrosarcoma (MSC) from other small blue round cell tumors. ${ }^{21}$ The p53 is a tumor suppression protein that regulates the transcription of genes important in cell cycle arrest and in apoptosis. ${ }^{18}$

We suspect this aggressive primitive tumor led to a neuroectodermal trend or an odontogenic trend ( - Table 4 ), but with the latter very primitive. Furthermore, we considered biphasic tumors with metastasis potential such as MEC, Ewing's sarcoma/PNET, odontogenic carcinosarcoma, neuroblastoma, MSC, synovial sarcoma, and desmoplastic small round cell tumor (DSRCT).

Ewing's sarcoma, now labeled by the World Health Organization $(\mathrm{WHO})^{7}$ as the same tumor as PNET, is a highgrade sarcoma of primitive small round cells. These tumor types were formerly distinguished based on the quantity of neuroectodermal differentiation, which is more often present in PNET. Ewing's sarcoma/PNET occurs mostly in children, but not exclusively to this group. There is a predominance in males. The head and neck are not usual sites, but the mandible and skull are mainly affected in this region. Commonly, pain and swelling are associated, with Ewing's sarcoma/PNET. It shows aggressive behavior and growth quickly, following general clinical features including mass lesion. This tumor is composed of small round cells with some mitotic activity, 
Table 4 Pediatric mandibular tumors comparative nature

\begin{tabular}{|c|c|c|c|c|c|}
\hline \multirow[t]{2}{*}{ Tumor } & \multicolumn{5}{|c|}{ Pathological features } \\
\hline & Localization & Clinical & Histopathological & Origin & $\begin{array}{l}\text { Immunohistochemical } \\
\text { profile }\end{array}$ \\
\hline $\begin{array}{l}\text { Odontogenic } \\
\text { carcinosarcoma }\end{array}$ & Mandible $^{7}$ & $\begin{array}{l}\text { Expansion of } \\
\text { body and ramus } \\
\text { of mandible; pain- } \\
\text { less or lip with } \\
\text { numbness }\end{array}$ & $\begin{array}{l}\text { Cord-like epithelial } \\
\text { branching separated } \\
\text { by stroma with } \\
\text { hypercellular fibro- } \\
\text { blastic; pleomorphic } \\
\text { cells, bizarre nuclei, } \\
\text { and some mitosis. } \\
\text { Epithelial structure } \\
\text { malingnant }^{7}\end{array}$ & $\begin{array}{l}\text { Epithelial and mes- } \\
\text { enchymal, both } \\
\text { malignant }^{7}\end{array}$ & $\mathrm{p} 53, \mathrm{~K}_{\mathrm{i}}-67^{7}$ \\
\hline $\begin{array}{l}\text { Ameloblastic } \\
\text { fibrosarcoma }\end{array}$ & $\begin{array}{l}\text { Posterior } \\
\text { jaws }^{7}\end{array}$ & $\begin{array}{l}\text { Expansile mass } \\
\text { with deficit of } \\
\text { nerve }^{7}\end{array}$ & $\begin{array}{l}\text { Bland-like benign } \\
\text { epithelial component; } \\
\text { malignant mes- } \\
\text { enchymal; nuclear } \\
\text { crowding, hypercel- } \\
\text { lularity, some atypia } \\
\text { and mitoses }\end{array}$ & $\begin{array}{l}\text { Epithelial and } \\
\text { mesenchymal but } \\
\text { only the latter } \\
\text { malignant }^{7}\end{array}$ & $\begin{array}{l}\text { Ki67, BCl-2, PCNA, c-KIT, } \\
\text { p53 }\end{array}$ \\
\hline $\begin{array}{l}\text { Mucoepidermoid } \\
\text { carcinoma }\end{array}$ & $\begin{array}{l}\text { Primary } \\
\text { intraosseous } \\
\text { are rare }^{7}\end{array}$ & $\begin{array}{l}\text { Depends on site, } \\
\text { size, and grade. } \\
\text { Intraosseous site } \\
\text { was not specified }^{7}\end{array}$ & $\begin{array}{l}\text { Squamoid compo- } \\
\text { nent; clear-cell, onco- } \\
\text { cytic and sclerosing } \\
\text { variants can occur }{ }^{7}\end{array}$ & Salivary gland ${ }^{7}$ & $\begin{array}{l}\text { Usually positive for CK5, } \\
\text { CK6, CK7, CK8, CK14, } \\
\text { CK18, CK19, EMA, CEA, } \\
\text { p63. Focal expression of } \\
\text { S100, c-KIT, glial fibrillary } \\
\text { acidic protein (GFAP), and } \\
\text { vimentin }^{17}\end{array}$ \\
\hline $\begin{array}{l}\text { Ewing's sarcoma/ } \\
\text { PNET }\end{array}$ & $\begin{array}{l}\text { Skull and } \\
\text { mandible }\end{array}$ & $\begin{array}{l}\text { Pain, mass lesion, } \\
\text { nasal obstruction }\end{array}$ & $\begin{array}{l}\text { Cord-like appearance, } \\
\text { small round cells, } \\
\text { mitotic activity }\end{array}$ & Neuroectodermal $^{7}$ & $\begin{array}{l}\text { NSE, S100 protein, synapto- } \\
\text { physin, chromogranin, NFP, } \\
\text { GFAP, CD } 117^{7}\end{array}$ \\
\hline Synovial sarcoma & Mandible $^{32}$ & $\begin{array}{l}\text { Palpable, deep- } \\
\text { seated swellings, } \\
\text { with or without } \\
\text { associated pain or } \\
\text { tenderness }^{7}\end{array}$ & $\begin{array}{l}\text { Several monophasic } \\
\text { subtypes (i.e., spin- } \\
\text { dle-cell, calcifying/ } \\
\text { ossifying, myxoid, and } \\
\text { poorly differentiated) } \\
\text { and biphasic subtypes } \\
\text { with glandular or solid } \\
\text { epithelial cells }{ }^{7}\end{array}$ & Mesenchymal ${ }^{7}$ & $\begin{array}{l}\text { CK, EMA, vimentin, } \\
\text { CD68, CD-99, E-cadherin, } \\
\text { Collagen IV }{ }^{19}\end{array}$ \\
\hline $\begin{array}{l}\text { Mesenchymal } \\
\text { chondrosarcoma }\end{array}$ & Mandible $^{31}$ & $\begin{array}{l}\text { Swelling, firm, } \\
\text { hard mass } \\
\text { destroying the } \\
\text { jaw bones }{ }^{31}\end{array}$ & $\begin{array}{l}\text { Bimorphic pattern } \\
\text { composed of islands } \\
\text { of well differentiated } \\
\text { hyaline cartilage } \\
\text { juxtaposed to a small, } \\
\text { round cell undifferen- } \\
\text { tiated malignancy }^{31}\end{array}$ & Mesenchymal $^{31}$ & $\begin{array}{l}\text { S100, vimentin, CD57, } \\
\text { SOX9 }^{19}\end{array}$ \\
\hline $\begin{array}{l}\text { Desmoplastic small } \\
\text { round cell tumor }\end{array}$ & $\begin{array}{l}\text { Abdominal or } \\
\text { pelvic cavity }{ }^{35}\end{array}$ & $\begin{array}{l}\text { Abdominal pain, } \\
\text { weight loss, } \\
\text { umbilical hernia, } \\
\text { ascites, increased } \\
\text { abdominal girth, } \\
\text { constipation, } \\
\text { hepatomegaly, } \\
\text { and splenomeg- } \\
\text { aly34 }\end{array}$ & $\begin{array}{l}\text { Solid sheets, large } \\
\text { nests, small clumps, } \\
\text { or cords of cohesive, } \\
\text { small, round, ovoid, or } \\
\text { spindled cells lying in } \\
\text { a hypocellular, desmo- } \\
\text { plastic, collagenous } \\
\text { stroma }^{34}\end{array}$ & Mesenchymal $^{34}$ & $\begin{array}{l}\text { NSE, Desmin, CK/EMA, } \\
\text { WT1 }^{19}\end{array}$ \\
\hline Neuroblastoma & $\begin{array}{l}\text { Adrenal } \\
\text { medulla }\end{array}$ & $\begin{array}{l}\text { Palpable abdomi- } \\
\text { nal abnormalities } \\
\text { and/or complaints } \\
\text { related to mass } \\
\text { effect on adjacent } \\
\text { organ systems }{ }^{24}\end{array}$ & $\begin{array}{l}\text { Nests, lobules, or } \\
\text { sheets of cells, often } \\
\text { separated by richly } \\
\text { vascular or hyalinized } \\
\text { fibrous stroma }\end{array}$ & $\begin{array}{l}\text { Ectodermal neural } \\
\text { crest cell }^{24}\end{array}$ & $\begin{array}{l}\text { NB84, MAP-2, neurofila- } \\
\text { ment, synaptophysin, NSE, } \\
\text { protein gene product } 9.5 \text {, } \\
\beta \text {-catenin, CD56 }{ }^{17}\end{array}$ \\
\hline
\end{tabular}

Abbreviations: CEA, carcinoembryonic antigen; EMA, epithelial membrane antigen NFP, neurofilament protein; NSE, neuron specific enolase; MAP-2, microtubule associated protein-2; PCNA, proliferating cell nuclear antigen; PNET, primitive neuroectodermal tumor. 
and spindled or clear-cell variants can occur. A PAS-positive reaction is present, and cytokeratins are stained in one-third of cases. Also, neural marker S-100 is reactive. Metastasis can occur, but mostly in cases in lungs and bones. No mandible-to-humerus metastasis was found by searching in the literature. ${ }^{5,7,22}$

Neuroblastoma is a commonly solid tumor in pediatric patients, arises from the ectodermal NCCs of the sympathetic nervous system, most commonly in the adrenal medulla. ${ }^{23,24}$ This tumor is detected as metastatic presentation in $~ 60$ to $70 \%{ }^{25}$ The mandible is an unusual site for neuroblastoma. ${ }^{26}$

MSC, histologically a biphasic pattern of both small cells and islands of atypical cartilage, is a rare high-grade of variant of chondrosarcoma. ${ }^{27}$ The predilection is in female and appears in the nervous system in patients at age 20 to 30 or in soft tissues in patients at age 40 or older. ${ }^{28}$ It is an aggressive tumor with high tendency to metastasize to the lungs, lymph nodes, and other bones. ${ }^{29,30}$ However, MSC originating from the mandible has different treatment and outcomes. Vencio et al reviewed a clinicopathologic study of 19 cases of MSC of the jaw bones, and confirmed the propensity to occur in children and young adult, and suggested a better prognosis than for other sites. ${ }^{31}$

Synovial sarcoma is soft tissue tumor that rarely affects the head and neck region, especially in the mandible. ${ }^{32}$ It is a mesenchymal malignancy, microscopically showing a biphasic appearance with distinct epithelial and spindle cell components, involving predominantly young adults, and regardless of its name, this tumor is commonly diagnosed in areas having no relation with synovial structures. ${ }^{33}$

DSRCT is an aggressive, malignant tumor usually involving the abdominal or pelvic cavity of children. Histologically presents small round cells organized in nests and separated by a dense collagenized and desmoplastic stroma. ${ }^{19,34}$ Küpeli et al reported a case of DSRCT in an unexpected site, the mandible, with a recurrence in the foot. ${ }^{35}$

Due to the aggressive and primitive nature of the tumor, two odontogenic tumor diagnoses were truly considered in the case: odontogenic carcinosarcoma and ameloblastic fibrosarcoma (AFS). The difference between both remains in the malignancy of the epithelial component. ${ }^{7}$

According to the WHO, odontogenic carcinosarcoma is a very rare malignant mixed-odontogenic neoplasm, with the jaw being the only reported site. Clinically, the tumor causes asymptomatic expansion of the body and ramus of the mandible. The cortical bone shows poorly defined borders in radiographic analysis. Both epithelial and mesenchymal tissues exhibit malignancy. The histopathology of odontogenic carcinosarcoma reveals epithelial cords with hyperchromatic nuclei separated by hypercellular fibroblastic stroma and pleomorphic cells, some with mitosis. Malignant spindle cell proliferation may be associated with ameloblastic carcinoma and is well identified as sarcomatoid ameloblastic carcinoma instead of odontogenic carcinosarcoma. ${ }^{7}$

AFS is an odontogenic sarcoma that differs from odontogenic carcinosarcoma's benign epithelial component. Some researchers believe that AFS arises from a pre-existing benign ameloblastic fibroma. AFS affects patients of any age, but the second decade of life has demonstrated elevated manifestation. There is a prevalence of AFS in males. Preference for the mandible was noted, especially in posterior jaws. An expansible mass is a clinical feature. Histopathology reports mesenchymal component malignancy, but a benign epithelial component with peripheral palisading, cytological atypia, and mitoses. . $^{736}$

However, there was an important factor hindering an appropriate diagnosis process in this case: the inequalities of the health system in Brazil. The public service demand has increased along with a human resource shortage. The northern region of Brazil in particular has had an insufficient health services network identified, while the capitals harbor medium- and high-complexity services. Developed regions have better attendance; hence, they have more structure and better conditions. This pattern is observed in the southeast and south compared with northern and northeastern areas. ${ }^{37-39}$ The additional investigation in this case was performed in another region because there is no center for immunohistochemical analysis in the author's region, limiting clinical takes and leading to conduct changes. Once the patient died, the public health service does not pay highly complex biomolecular examinations, nor did the family allow the body to be exhumed for further investigation.

Early diagnosis can prevent further lethal development of such aggressive mandibular tumor. Clinicians and pathologists must identify these unusual features that lead rapidly to a severe and sudden lesion resolution as metastasis followed by paraneoplastic syndromes (PNS). Immunohistochemistry is the primary choice to perform additional investigation once the histopathological report results inconclusive.

It is important to note that a series of disorders deemed PNS may take a rapid course leading to remote effects produced indirectly by the tumor, such as endocrine, cutaneous or dermatologic, hematologic, osteoarticular or rheumatologic, neurologic, and ocular syndromes. ${ }^{40}$ Rahbar et al presented a case of Cushing's syndrome due to adrenocorticotropic-secreting peripheral PNET. ${ }^{41}$ de Souza Azevedo et al reported of synchronous orofacial granulomatosis associated with MEC, however, the identification of associated pathological processes as a PNS is difficult depending on the constancy shown in a series of cases. Such large casuistic is difficult to obtain in rare tumors. ${ }^{42}$ Usually, PNSs are often associated with small cell carcinoma and squamous cell carcinoma of the lung, oral cancers are less commonly related to PNSs. ${ }^{43}$

\section{Conclusion}

The diagnosis process could not be finished due to the patient's demise. This rare primitive tumor demonstrated unusual features. Immunohistochemical markers and histomorphological aspects did not indicate specific characteristics, and clinically, it expressed aggressive behavior. This fact made it difficult to execute the treatment plan, aggravating the patient's clinical condition. The lack of resources for less-favored regions of Brazil impairs rapid biomolecular exams such as immunohistochemical resulting in delay of appropriate therapeutic procedures. 


\section{Authors' Contributions}

All authors contributed to the study conception and design. Material preparation, data collection, and analysis were performed by T.N.P and M.G.M.L. The first draft of the manuscript was written by T.N.P.

L.N.C., A.L.T.D., F.A.B., and N.S. operated and treated the patients studied, and reviewed the manuscript. All authors read and approved the final manuscript for publication. T.N.P. takes full responsibility for the work as a whole, including the study design, access to data, and the decision to submit and publish the manuscript.

\section{Ethical Approval}

All procedures performed in studies involving human participants were in accordance with the ethical standards of the institutional and national research committee (03878718.8.0000.5016 CEP/CONEP - Brazilian Research Ethics Committee) and with the 1964 Helsinki declaration and its later amendments or comparable ethical standards.

\section{Informed Consent}

Patient included in the study couldn't be contacted due to death and change of registration data that prevent his contact; it was requested to waive the informed consent form of these cases.

\section{Funding}

None.

\section{Conflict of Interest}

None declared.

\section{References}

1 Abramowicz S, Goldwaser BR, Troulis MJ, Padwa BL, Kaban LB. Primary jaw tumors in children. J Oral Maxillofac Surg 2013;71(1):47-52

2 Montañez FM. Aggressive mandibular tumors in pediatric patients. Report of 4 cases. Rev Odont Mex 2016;20(2):125-131

3 Perry KS, Tkaczuk AT, Caccamese JF Jr, Ord RA, Pereira KD. Tumors of the pediatric maxillofacial skeleton: a 20-year clinical study. JAMA Otolaryngol Head Neck Surg 2015;141(1):40-44

4 Zwetyenga N, Broly E, Guillier D, Hallier A, Levasseur J, Moris V. Classification proposed of malignant intraosseous odontogenic tumors (MIOT) J Stomatol Oral Maxillofac Surg 2017;118(3):143-146

5 Somers GR. Ewing family tumours: a paediatric perspective. In Mini-symposium: pathology of paediatric neoplasms. Diag Histopath; $2014 ; 20(2): 49-55$

6 Carlson ER, August M, Ruggiero SL. Locally aggressive benign processes of the oral and maxillofacial region. Selected Readings Oral Maxillofac Surg 2004;12(3):1-52

7 El-Naggr AK, Chan JKC, Grandis JR, Takata T, Slootweg PJ. World Health Organization Classification of Head and Neck Tumors. 4th edition. Lyon, France: IARC Press; 2017

8 Shafer WG, Hine KM, Levy BM. Shafer's Textbook of Oral Pathology. 7th edition. India: Elsevier Inc; 2012

9 Nanci A. Ten Cate's Oral Histology. 8th edition. St Louis: Mosby; 2012

10 Su CC, Liu CL, Lin CN, Leea YH, Shen KH. A rare, highly aggressive primitive neuroectodermal tumor of the kidney: case report and literature review. Urol Sci 2012;23(2):58-60
11 Kuberappa PH, Bagalad BS, Ananthaneni A, Kiresur MA, Srinivas GV. Certainty of S100 from physiology to pathology. J Clin Diagn Res 2016;10(6):ZE10-ZE15

12 Sinha A, Chandra S, Raj V, Zaidi I, Saxena S, Dwivedi R. Expression of p63 in potentially malignant and malignant oral lesions. J Oral Biol Craniofac Res 2015;5(3):165-172

13 Moll UM, Slade N. p63 and p73: roles in development and tumor formation. Mol Cancer Res 2004;2(7):371-386

14 Barak V, Goike H, Panaretakis KW, Einarsson R. Clinical utility of cytokeratins as tumor markers. Clin Biochem 2004;37(7):529-540

15 Da Silva LAB, Da Silva LP, Mororó ABG, Germano AR, Da Costa Miguel, MC. Extensive salivary myoepithelioma in pediatric patient. J Oral Maxillofac Surg Med Pathol 2018;30(1):74-78

16 Hunt JL. Barnes L. Immunohistology of head and neck neoplasms. In: Dabbs DJ, ed. Diagnostic Immunohistochemistry. 2nd edition. Philadelphia, PA: Churchill Livingstone, Elsevier; 2006 227-260

17 Zhu S, Schuerch C, Hunt J. Review and updates of immunohistochemistry in selected salivary gland and head and neck tumors. Arch Pathol Lab Med 2015;139(1):55-66

18 Rezaei N. Cancer immunology. 2nd edition. Switzerland: Springer Nature; 2020

19 Lin F, Prichard J. Handbook of Practical Immunohistochemistry: Frequently Asked Questions. 2nd edition. New York: Springer Verlag; 2015

20 Binh MB, Sastre-Garau X, Guillou L, et al. MDM2 and CDK4 immunostainings are useful adjuncts in diagnosing well-differentiated and dedifferentiated liposarcoma subtypes: a comparative analysis of 559 soft tissue neoplasms with genetic data. Am J Surg Pathol 2005;29(10):1340-1347

21 Wehrli BM, Huang W, De Crombrugghe B, Ayala AG, Czerniak B. Sox9, a master regulator of chondrogenesis, distinguishes mesenchymal chondrosarcoma from other small blue round cell tumors. Hum Pathol 2003;34(3):263-269

22 Urs AB, Kumar P, Rawat G, Mohanty S. Ewing's sarcoma of the jaws: an institutional study of four cases. Int J Pediatr Otorhinolaryngol Extra 2016;13:33-39

23 Parker CA, Liess BD, Gov-Ari E, Sramek BW. Metastatic neuroblastoma to the mandible: an unusual presentation. Am J Otolaryngol 2011;32(5):438-440

24 Wade G, Revels J, Hartman L, Brown W. Pediatric mandibular metastasis: A rare finding of neuroblastoma. Radiol Case Rep 2017;13(1):289-294

25 Kembhavi SA, Shah S, Rangarajan V, Qureshi S, Popat P, Kurkure P. Imaging in neuroblastoma: An update. Indian J Radiol Imaging 2015;25(2):129-136

26 Tang PH, Cohen PA. Primary neuroblastoma of the mandible. Singapore Med J 2009;50(1):e5-e7

27 Xu J, Li D, Xie L, Tang S, Guo W. Mesenchymal chondrosarcoma of bone and soft tissue: a systematic review of 107 patients in the past 20 years. PLoS One 2015;10(4):e012221610.1371/ journal.pone.0122216

28 Louvet C, de Gramont A, Krulik M, et al. Extraskeletal mesenchymal chondrosarcoma: case report and review of the literature. J Clin Oncol 1985;3(6):858-863

29 Nakashima Y, Unni KK, Shives TC, Swee RG, Dahlin DC. Mesenchymal chondrosarcoma of bone and soft tissue. A review of 111 cases. Cancer 1986;57(12):2444-2453

30 Salvati M, Caroli E, Frati A, et al. Central nervous system mesenchymal chondrosarcoma. J Exp Clin Cancer Res 2005;24(2):317-324

31 Vencio EF, Reeve CM, Unni KK, Nascimento AG. Mesenchymal chondrosarcoma of the jaw bones: clinicopathologic study of 19 cases. Cancer 1998;82(12):2350-2355

32 Kartha SS, Bumpous JM. Synovial cell sarcoma: diagnosis, treatment, and outcomes. Laryngoscope 2002;112(11):1979-1982 
33 Khalili M, Eshghyar N, Ensani F, Shakib PA. Synovial sarcoma of the mandible. J Res Med Sci 2012;17(11):1082-1085

34 Lae ME, Roche PC, Jin L, Lloyd RV, Nascimento AG. Desmoplastic small round cell tumor: a clinicopathologic, immunohistochemical, and molecular study of 32 tumors. Am J Surg Pathol 2002;26(7):823-835

35 Küpeli S, Cağlar K, Birgen D, Sungur A, Varan A. Desmoplastic small round cell tumor of the mandible in a child with unusual plantar metastasis. J Pediatr Hematol Oncol 2010;32(4): e155-e157

36 Khalili M, Shakib PA. Ameloblastic fibrosarcoma of the upper jaw: report of a rare case with long-term follow-up. Dent Res J (Isfahan) 2013;10(1):112-115

37 Arruda P, Vaitsman J. Health policy in emerging economies: innovations and challenges. Brasília: Policy in Focus; 2016

38 Garnelo L, Sousa ABL, Silva COD. Health regionalization in Amazonas: progress and challenges. Cien Saude Colet 2017;22(4):1225-1234
39 Uchimura LYT, Felisberto E, Fusaro ER, Ferreira MP, Viana ALA. Evaluation performance in health regions. Rev Bras Saúde Matern Infant 2017;17(1):259-270

40 Toro C, Rinaldo A, Silver CE, Politi M, Ferlito A. Paraneoplastic syndromes in patients with oral cancer. Oral Oncol 2010;46(1):14-18

41 Rahbar M, Rahbar M, Bahoush G. Peripheral primitive neuroectodermal tumor associated with paraneoplastic Cushing's syndrome: the rare case. Ann Med Surg (Lond) 2018;37(37):21-24

42 de Souza Azevedo R, Abrahão AC, de Albuquerque EB. Synchronous orofacial granulomatosis and mucoepidermoid carcinoma: paraneoplastic syndrome or coincidence? Oral Surg Oral Med Oral Pathol Oral Radiol Endod 2008;106(2):e40-e45

43 Feller L, Wood NH, Khammissa RA, et al. Oral cancer-associated paraneoplastic syndromes. SADJ 2010;65(9):424-426 